\title{
Ground Water Development Problems in Costal Belts of Odisha, India
}

\author{
Kishore Chandra Senapati, Asoka Kumar Das and Shishira Kanta Behera* \\ Institute of Agricultural Sciences, SOA University, India \\ *Corresponding author
}

\section{A B S T R A C T}

Ke y w o r d s
$\begin{aligned} & \text { Coastal belt, saline } \\ & \text { and fresh water, } \\ & \text { aquifers, geological } \\ & \text { formations, } \\ & \text { hydraulic properties }\end{aligned}$
Article Info
$\begin{aligned} & \text { Accepted: } \\ & \text { 14 May } 2020 \\ & \text { Available Online: } \\ & \text { 10 June } 2020\end{aligned}$

Crescentic coastal belt of Odisha, stretching about 480kms long from Digha, Balasore to Chilika and 10 to $15 \mathrm{kms}$. broad occupies the cutfall regions of major rivers like the Mahanadi , Brahmani, Baitarani, Subarnarekha. The belt is underlain by a thick pile of unconsolidated sediments of Miocen to recent age. Alternations of sand and clay beds, of various shades, grades and texture comprise the sediments, horizons, often attaining individual thickness of over twenty-five meters, from the principal aquifers. Tube well tapping 35 to 65 meters of aquifer yield 140 to $270 \mathrm{M} 3$ per hour, for drawdowns varying from 3 to 13 meters. Both the fresh and saline ground water co-exist in the system, often interchanging their position. This paper spalls out the hydro-geological framework, delineates the regional disposition of fresh and saline ground water bodies, recommends special techniques of production wall constructions , stressed the need for scientific management of fresh ground water resources and rigorous monitoring to safeguard against salt water contamination.

\section{Introduction}

The costal belt of Odisha, stretching for over four hundred eighty kilometers from Digha, Balasore to lake Chilika represent one of the most fertile land in the eastern parts of the country. It covers parts of the districts of Balasore, Bhadrak, Jajpur, Kenrapara, Jagatsinghpur, Cutttack , Puri and Ganjam in Odisha, which forms the grainery of the region. The region very often witnesses the onslaught of floods and cyclone causing extensive damage, particularly in the agricultural sector, Erratic behavior of the monsoon have also frequently added difficulties in sustaining agricultural productivity . Occurrence of adequate ground water resources have introduced an element of reliability and raised hopes of not only stabilizing agriculture but adoption of multiple cropping pattern.

Scientific management of the fresh ground water resources, safeguarding it from the seawater encroachment problem will undoubtedly boost up the agro economy of the region. 


\section{Geographical features}

The coastal belt constitutes a narrow elongated sub-parallel to the coast low laying area, relief seldom rising above the 1.5 meters above sea level characterized by marshy land, disected by creeks, sand bars, and an extensive alluvial tract with a feebly undulating topography expanding itself to its best in the region of Brahmani -Mahanadi delta system gradually tapering itself towards and Chilika lake region. The plains are fringed by the actuate upland tract marked by laterite capping of uneven thickness, eventually taken over upalope by the hills of Archaean crystllines and associated rock units. A sub-tropical monsoonic climate prevails in the coastal region. Winters are rather moderate, summers are hot with day temperature occasionally raising up to $45^{\circ} \mathrm{C}$ and rainy season extending from mid-June to mid-October. The monsoons bring the build of the annual rainfall with a regional average of the order of $1500 \mathrm{~mm}$.

Paddy is the principal Kharif crop of the region and is largely rainfed. In selected areas where irrigation facilities are available the second crop i.e. "Rabi" is coming up.

\section{Hydrogeological conditions}

Rocks belonging to Achaean age are exposed along with the north -western, western and south western periphery of the costal tract.The most commonly me rock types are the orthogenesis, charnockites and the khondalitee. At Binjharpur in Cuttack district, amphibolites occur at depths of 80 metres below land surface and at Arilo (Jagatsinghpur) the granite gneiss is met surface indicating the nature of the bed rock configuration on the costal region.

The Baripada marine sedimentaries are exposed in Mayurbjhanj district adjacent to
Balasore district. The sedimentary chiefly comprise of yellow to brownish yellow fossiliferous limestones and clays. In the costal belt, such fossilifarous limestones are encountered at depths 80 to 150 meters in the upstream side of the deltaic tract and between 20 to 300 meters below land surface in the downstream side of the deltaic tract. The unconsolidated sediments are essentially a sequence of clays, sands and gravel exhibiting wide variation both in grade and colour grays. The sands are of quartzo- felspathic material often associated with gravel calcasediments assume great thickness in the vicinity of the coast.

These sand horizons, occurring at different depth levels, from the aquifer. The aquifers tend to exihibit rather a regionally extensive character.

\section{Shallow aquifers}

Sands occurring in the depth span of 20 to 80 meters in most of the river basin in this belt from effective shallow aquifers. Except in the Kangsavati basin, these shallow aquifers are mostly fresh water type and when tapped by tube wells yield from 180 to $315 \mathrm{M} 3$ per hour for drawdowns varying from 5 to 15 meters. The yield capacity of the shallow aquifers, however appear to increase progressively down slope. Shallow aquifers, however, in the 10 kilometer linear belt along the coast and about 50 kilometers wide belt in the J Jang Jagannathpur tract in the Mahanadi delta contain saline water. However, down coast say from Arilo, Juinti to Puri the shallow aquifers are again fresh water bearing and form secure of dependable ground water supplies. Shallow aquifers are being extensively tapped in the Cuttack, Puri and Balasore districts by means of private tube wells for irrigation purposes and also form effective source of supplementary water supplies in the canal command areas. 


\section{Deeper aquifers}

Away from the upland tracts, almost in the entire coastal belt occur several deep aquiers which show variations both in their disposition and extension. Towards the inland half, the deep aquifer is somewhat flatly disposed. But in the half towards the coast the deeper aquifers show conspicuous dip towards the coast direction and the amount of the deep appear to increase progressively coastward.

In the Subarnarekha-Kangsavati basins the deeper aquifers are made up of very fine quartz-felspathic sands often with gravels and give fairly large yield when tapped by tube wells. In the Baitarani and Brahmani basin areas the deeper aquifers continue to be under confined conditions.

In parts of the Balasore district the deeper aquifers when tapped by tube wells often flow naturally at land surface. Tube wells yield around $225 \mathrm{M} 3$ per hour for economic draw downs.

In the Mahanadi delta region, the deeper aquifers, comprising chiefly of quartzo felspathic sands and gravel attain significant thickness. Whereas in certain parts of the delta a the deeper aquifers through productions wells give yield of the order of 270M3 per hour for draw downs in the neighborhood of 15 meters, in other parts the deeper aquifers being saline cannot be consolidated as source of water supply.

In the area beyond Brahmagiri upto lake Chilika region disposition of the aquifers system from the lithological standpoint is expected to be maintained. However, from the standpoint of being a source for water supply the deeper aquifers are expected to be the fresh water bearing overlain by rather brackish water aquifers.

\section{Hydraulic properties}

The two most important hydraulic characteristics of water bearing formation are its transmissivity and storage coefficient. Transmissvity is defined as the rate of flow under a hydraulic gradient equal to unity through a cross section of unit width over the whole thickness of the aquifer. It has the dimension of length over time multiplied by length. In this paper it is expressed as M3/D/M. The pump test data analyses over wide range of tubewells in the coastal tracts have given the following range of transmissivity (in $\mathrm{M} 3 / \mathrm{D} / \mathrm{M}$ ) of the deeper aquifers 1999 to 1786 in SubarnarekhaBudhabalanga basins, 375 to 4721 in Baitarani-Brahmani basin, 3843 to 6622 in Mahanadi delta and 434 to 1840 in Kangavati basin.

The storage coefficient is unusually defined as the volume of water released or stored per unit surface are of the aquifer per unit change in the component of head normal to that surface. It is a dimensionless parameter, refers to the confined aquifer and depends on the elastic properties of aquifer material and the fluid. The test data analyses of the above region have indicated a general range of storage coefficient $3.35 \times 10^{-4}$ to $2.46 \times 10^{-6}$. These values of the storage coefficient demonstrate the confined nature of the deeper aquifers tapped by the production tube wells.

\section{Specific capacity}

It is defiend usually as the relationship between the rate of discharge of water per unit drawdown. It is expressed in litres per minute per metre of drawdown (LPM/M). the specific capacity values were found to be 210 to 773 in Subarnarekha-Budhabalanga basin, 217 to 530 in Baitarani-Brahmani basin, 1204 to 1448 in Mahanadi basin and 148 to 456 in Kangavati basin. 


\section{Chemical quality of ground water}

Subarnarekha-Budhabalanga basin areas have fairly good quality with Chlorides and total dissolved solid ranging between 20 to 80 per and 150 to 700 ppm respectively. Brahmani Baitarini basins have the chlorides range from 20 to $140 \mathrm{ppm}$ and total dissolved solid from 200 to $700 \mathrm{ppm}$. But in Mahanadi delta area chlorides range from 200 to $400 \mathrm{ppm}$ and total dissolved solids from 800 to $1200 \mathrm{ppm}$.

\section{Saline and fresh ground water relationships}

The aquifer system under laying the coastal region demonstrate a wide variation in the disposition of the fresh and saline ground water bodies. Throughout the entire belt both the type of ground water co exist in the ground water system but do not maintain any steady relationship. In the Kangasvati basin, the coastal aquifers have saline ground water occurring down to depths of 125 metres, below which occurs the fresh ground water body. In a 10-15 kms wide belt of the Subarnarekha, Budhabalnga, Baitarani and Brahmani, in the proximity of the coast the upper aquifers.

The diagram depiote the three dimensional relationship of the saline and fresh ground water bodies. Down coast of the Jajanga Jagannathpur tract, in the south westerly direction the hydrochmeical profile suddenly undergoes a reversal. From Arilo-Juinti area. Down coast to Puri, the fresh ground water comes on top and over lie the saline ground water body. At Puri, however, below about 150 mteres depths a second fresh water bearing aquifer occurs, the regional extension particularly its intake area is yet to be established. Further down coast of Puri, at Balanga on again the saline ground water deepens itself like at Masakhani to over 100 metres. This perhaps is a pointer to the reversal of hydro-chemical profile once more. Indications are that hereafter down the coast upto Chilka Lake regions the coastal tracts once again have the upper aquifers which are saline.Continue to be saline down to depths varying from 100 to 135 metres. In the Mahanadi delta region, saline ground water extends far inland, about $60 \mathrm{Kms}$. from the coast. The saline and fresh ground water relationship in this part of the Orissa Coast in shown in panel diagram below:Such subtle variations in the fresh saline ground water relationship in the coastal belt introduces an element of complexity which requires proper understanding and appreciation in the development of fresh ground water resources.

\section{Wall construction}

Success of the tube wells would depend on the judicious selection of fresh water aquifers, effective seal off of the saline aquifers. For alienation of saline and fresh water aquifers electric logging supported by specific some testing to establish actual quality of formation water must be the basis of selection of aquifer somes to be tapped. For effective examination of the upper saline aquifers quick settling cement plug should be provided in the gravel pack at the these level of the saline aquifer.

\section{Ground water development problems}

The principal aim of ground water development programme is to tap the ground water resource through structures which are capable of supplying on sustained basis the desired amount of water supply for intended use. In this coastal belt the occurrence of a large and extensive fresh ground water reservoir has been established. But success of extensive and intensive ground water development through tube wells underlines the need for precise knowledge of the aquifer geometry, chemical quality and the saline water and fresh water disposition. 


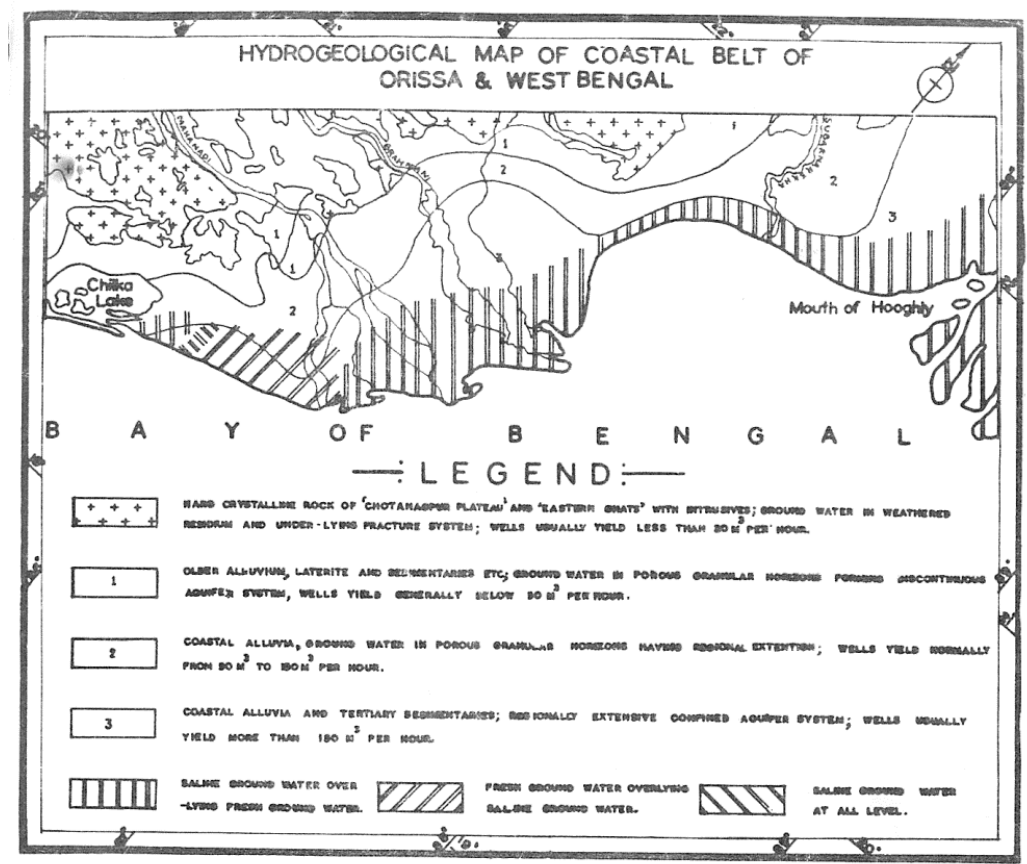

Fig.1

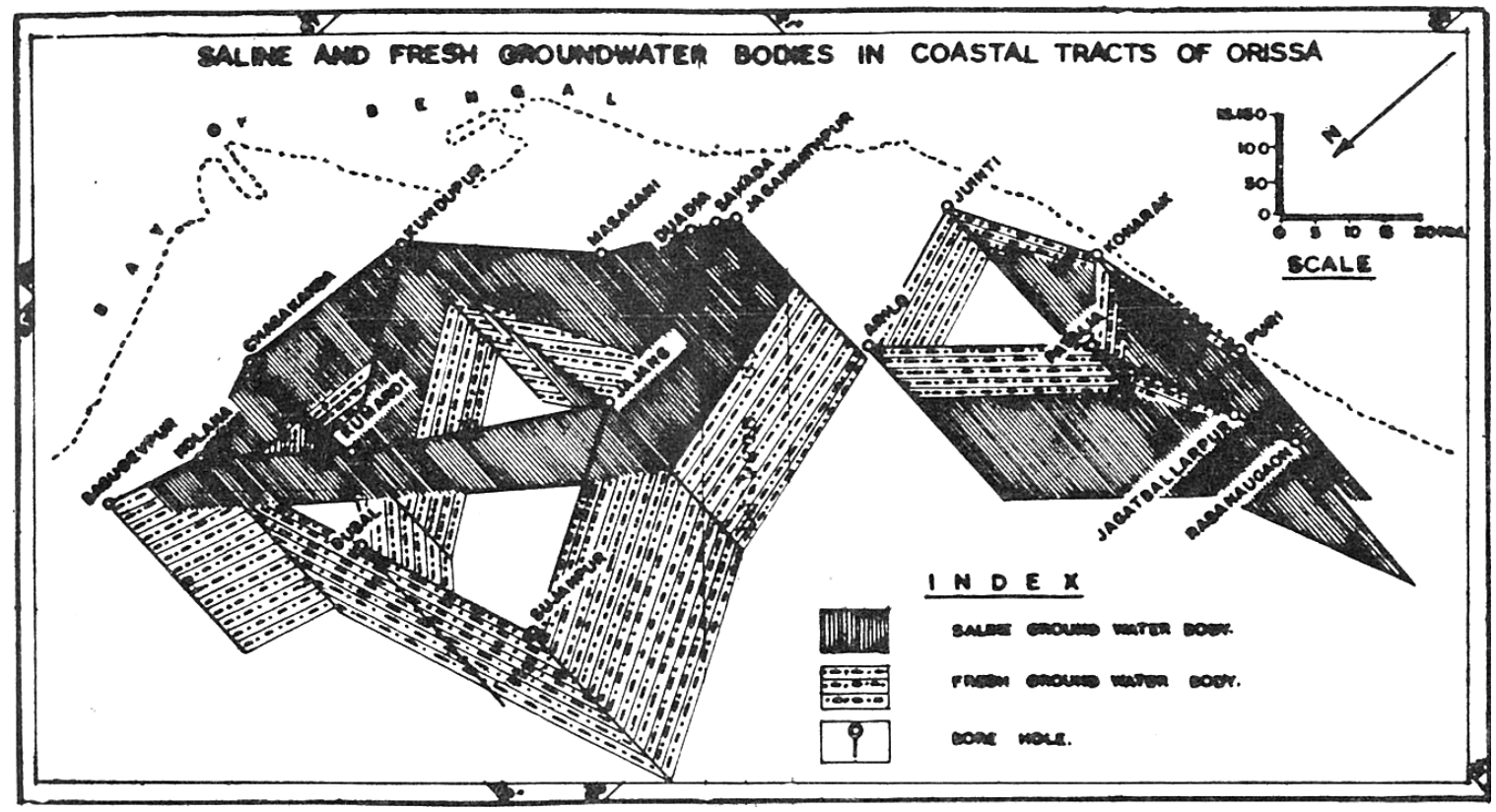

Fig.2 Saline and fresh groundwater bodies in Coastal tracts of Odisha

Well construction programme must proceed with cautious optimum particularly in sensitive and complex areas where the salinity profiles either undergo or are prone to undergo reverals. Since long term withdrawals are expected to introduce changes of chemical quality of the ground water supply, needed for controlled long duration rather time extended pumping tests cannot be over-emphasized for obtaining a measure of such possible changes on prolonged pumping. 
Ground water structures are required to have reasonably long life to provide dependable quantities of water supplies. Presence saline ground water at varying depth levels will expose the casing material to corrosion hazards. Need for appropriate quality of wall sealing materials which could withstand the effects of chemical hazards in ground water, should receive high priority.

The coastal belt of Odisha is underlain by a thick pile of unconsolidated sediments which contains regionally extensive and highly productive fresh water aquifer system. This enormous fresh ground water reservoir is associated with the saline ground water body occurring at various depths levels. This timeindependent ground water reservoir is available for extensive and intensive development both for agricultural and industrial us.

\section{Recommendations}

Scientific management of the ground water resources of this coastal belt should include:

Need oriented development on selective aquifer basis;

Regulation of ground water withdrawals as per sustained yield capacity related to unchanged chemical quality of formation water tapped by the structures;

Cumulative well field draft on the basis dependable time extended pumping tests to eliminate possibilities of salt water contamination;

Avoiding, excessive localized ground water overdrafts for preventing dangers of possible land subsidence in the immature deltaic soils;

Proper precaution from sea water ingress which would rather permanently dams the effected part of the fresh ground water reservoir; and

Most rigorous monitoring of the ground water levels and the chemical quality time to initiate timely remedial measures in safeguarding the precious fresh ground water reservoir from the menance of saline water contamination. These periodic data from field should be constantly fed back to headquarters for objective analyses, interpretation and formulation of appropriate corrective measures before it got too late.

\section{References}

Behera, S.K,(1994), Working of a group of partially penetrating shallow tube wells in confined aquifer, Ph.D thesis work, IIT, Kharagpur, West Bengal.

Behera, S.K,(2007), Salinity problems and its alleviation in the coastal command area of Odisha, Proceedings of Eastern Regional Workshop on Water Quality, India, CGWB, Ministry of Water Resources, Govt. of India.

Behera, S.K,(2009) ,Potential use of riverbank filtration for aquaculture and irrigation, Proceedings of Water Quality Management in Eastern Region, India, CGWB, Ministry of Water Resources, Govt. of India.

Dutt, D. K., (1977) Ground Water Conditions in porous formation with special references to coastal and deltaic aquifer system, Proe. Work shp on Expl. Tech. for Ground Water; COSTED.

Krusemen, G.P. and Darideder, N.A., (1970) Analysis and Evaluation of Pumping Test Data; Bull. 11, I.I.L.R.I.W., Natherlands.

Radhakrishna, I. and Dut, D.K., (1976) Ground Water Resources Evaluation in Selected Tracts of Coastal Orissa; CGWB, India (Mimeographed Report). 


\section{How to cite this article:}

Kishore Chandra Senapati, Asoka Kumar Das and Shishira Kanta Behera. 2020. Ground Water Development Problems in Costal Belts of Odisha, India. Int.J.Curr.Microbiol.App.Sci. 9(06): 307-313. doi: https://doi.org/10.20546/ijcmas.2020.906.040 